\title{
Association between household exposure and cycle threshold in COVID-19 infected health care workers
}

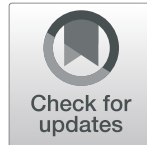

Ai Chien ${ }^{1,2}$, Sandra Domeracki ${ }^{1,3}$, Sandeep Guntur ${ }^{1,2}$, Kristopher Taylor ${ }^{1}$, Chuanyi M. Lu ${ }^{1,4}$, Harry Lampiris ${ }^{1,5}$ and Paul D. Blanc ${ }^{1,2^{*}}$ (D)

\begin{abstract}
Objective: Household SARS-COV-2 contact constitutes a high-risk exposure for health care workers (HCWs). Cycle threshold (Ct) of reverse transcriptase-polymerase chain reaction testing provides an estimate of COVID-19 viral load, which can inform clinical and workplace management. We assessed whether Ct values differed between HCWs with COVID-19 with and without household exposure.

Methods: We analyzed HCW COVID-19 cases whose Ct data could be compared. We defined low Ct at a cut-point approximating a viral load of $4.6 \times 10^{6}$ copies per ml. Logistic regression tested the association of household exposure and symptoms at diagnosis with a low Ct value.

Results: Of 77 HCWs with COVID-19, 20 were household exposures cases and 34 were symptomatic at testing (7 were both household-exposed and symptomatic at testing). Among household exposures, 9 of 20 (45\%) manifested lower Ct values compared to 14 of 57 (25\%) for all others. In a bivariate model, household exposure was not statistically associated with lower Ct (Odds Ratio [OR] 1.20; 95\% Confidence Interval [Cl] 0.97-1.51). In multivariable modelling both household exposure (OR] 1.3; 95\% Cl 1.03-1.6) and symptoms at diagnosis (OR 1.4; 95\% Cl 1.15-1.7) were associated with a low Ct value.

Discussion: Household exposure in HCWs with newly diagnosed COVID-19 was associated with lower Ct values, consistent with a higher viral load, supporting the hypothesis that contracting COVID-19 in that manner leads to a greater viral inoculum.
\end{abstract}

Keywords: COVID-19, Health care workers, Household exposure, Cycle threshold

\footnotetext{
* Correspondence: paul.blanc@ucsf.edu

'Occupational and Employee Health Section and Infectious Disease Section, Medical Service and Laboratory Medicine Service, San Francisco Veterans Affairs Health Care System, 4150 Clement St., San Francisco, CA 94121, USA

${ }^{2}$ Division of Occupational and Environmental Medicine, Department of Medicine, University of California San Francisco, San Francisco, USA Full list of author information is available at the end of the article
}

(C) The Author(s). 2021 Open Access This article is licensed under a Creative Commons Attribution 4.0 International License, which permits use, sharing, adaptation, distribution and reproduction in any medium or format, as long as you give appropriate credit to the original author(s) and the source, provide a link to the Creative Commons licence, and indicate if changes were made. The images or other third party material in this article are included in the article's Creative Commons licence, unless indicated otherwise in a credit line to the material. If material is not included in the article's Creative Commons licence and your intended use is not permitted by statutory regulation or exceeds the permitted use, you will need to obtain permission directly from the copyright holder. To view a copy of this licence, visit http://creativecommons.org/licenses/by/4.0/ The Creative Commons Public Domain Dedication waiver (http://creativecommons.org/publicdomain/zero/1.0/) applies to the data made available in this article, unless otherwise stated in a credit line to the data. 


\section{Introduction}

Cycle threshold $(\mathrm{Ct})$ of reverse transcriptase-polymerase chain reaction, the number of amplification cycles for the target gene to exceed threshold detection, can provide an estimate of SARS-COV-2 viral load and may be related to infectivity and disease severity [1]. Nonetheless, Ct quantification can be fraught with variability, especially across laboratories, and is not currently recommended as a measure to inform clinical management [2]. Among health care workers (HCWs) with COVID-19, Ct data have been analyzed in light of return-to-work protocols in one study and used in analysis of work-absence risk in another [3, 4].

Household exposure to SARS-COV-2 has been associated with a higher secondary attack rate than other sources of exposure, including acquisition in health care settings $[5,6]$. This presumably reflects a greater intensity of exposure to the virus in persons acquiring COVID-19. In a cohort of HCWs with acute SARSCOV-2COVID-19 infection and with well-characterized contact tracing, we assessed whether the Ct differed between those with illness likely contracted from a household member compared to all others.

\section{Methods}

As part of clinical quality improvement activities at the San Francisco Veterans Affairs Healthcare System, we analyzed positive SARS-COV-2 RT-PCR testing (nasopharyngeal or oropharyngeal swab). These included both symptomatic and asymptomatic employees (the latter tested due to exposure or in routine surveillance monitoring). We limited analysis to cases March 2020 through January 2021 whose initial positive testing was performed at the San Francisco Veterans Affairs Healthcare System laboratory using the same Abbott RealTime SARS-COV-2 assay providing directly comparable $\mathrm{Ct}$ values. The Abbott assay is United States Food and Drug Administration Emergency Use Authorization-approved as a qualitative test and was calibrated in-house using standard reference materials [3]. We excluded cases initially diagnosed with COVID-19 by use of other assays at our site or elsewhere.

We reviewed our employee health unit's COVID-19 database, using narrative information to identify whether infection was attributable to residing with someone whose COVID-19 preceded that of the employee. The database narrative text, in all cases, had been entered by one of four trained clinicians (two physicians and two advanced practice nurses) at the time of intake by interviewing the cases and was supplemented as appropriate by a nurse who carried out contact tracing. The interview specifically focused on potential sources of exposure, including any household contacts who were symptomatic or diagnosed with SARSCOV-2. The designation of a household source required that the narrative indicated onset of symptoms or diagnosis preceding the onset in the employee case in a time period consistent with the COVID-19 incubation period (2 to 14 days). A single researcher (author AC) categorized the employees on this basis, with adjudication when questions arose by another (author SD) using supplemental information garnered through the return-towork process for ill employees.

We also determined if the employee was symptomatic at initial testing. We defined symptomatic as log documentation of the employee reporting any of a standard check list of COVID-19 related complaints we routinely used to categorize any employees as a "person under investigation" (PUI). These included: a body temperature of 100 degrees Fahrenheit or greater, malaise or muscle ache, upper or lower respiratory complaints, loss of smell or taste, other neurological symptoms, gastrointestinal upset, or dermal or ocular complaints.

Because we anticipated that symptomatic status at the time of initial test positivity might be associated with a higher estimated viral load, we wanted to assess any confounding association between such symptomatic status and a household source of exposure. To do so, we tested the cross-tabulation of symptomatic status vs. household exposure (both defined dichotomously) using the Chi square. We defined low $\mathrm{Ct}$ (indicative of higher viral load) as a value below the lowest quartile cutoff among the non-household contact cases: a Ct of 9.32 (estimated viral load approximating $4.6 \times 10^{6}$ copies per $\mathrm{ml}$ ). We chose the lowest quartile rather than the median value of the referent HCWs (those without a household source) to reflect the lower threshold "tail" of these non-normally distributed data. Our laboratory standard curve established a linear correlation of lower $\mathrm{Ct}$ to higher viral load with this lower quartile cut-off being multiple orders of magnitude above the reliable limit of detection (the positive/negative test report used clinically). Logistic regression tested the association of household exposure alone or adjusted for symptomatic case status with low Ct (RStudio 2021; PBC, Boston, MA).

\section{Results}

Of 141 SARS-COV-2 infected employees, 64 were excluded because they did not have initial diagnostic testing performed with the Abbott RealTime at the SFVA HCS laboratory. Of 77 analyzed, 20 (26\%) were household exposures. Of these, 7 of 20 (35\%) were symptomatic at the time of initial testing, whereas 13 of 20 (65\%) were asymptomatic. Another 26 were symptomatic but did not have a household exposure source (total symptomatic, 33 of 77 [44\%]). The association between having a household exposure source and being symptomatic at the time of testing was not statistically significant $(p>$ 0.3 ). Of 20 household exposure cases, 9 (45\%) manifested lower Ct values; whereas 14 of 57 (25\%) nonhousehold exposure cases had lower $\mathrm{Ct}$ values. Table 1 
Table 1 Odds of Low Cycle Threshold (Ct) Among 77 COVID-19 Positive Health Care Workers

\begin{tabular}{|c|c|c|c|}
\hline Logistic Regression Model & Risk Factor (no. with risk factor) & Odds Ratio & $95 \% \mathrm{Cl}$ \\
\hline $\begin{array}{l}\text { Model } 1 \\
\text { Household Exposure Alone in Bivariate Model of Low Ct }\end{array}$ & Household Exposure (20) & 1.2 & $0.97-1.5$ \\
\hline \multirow{2}{*}{$\begin{array}{l}\text { Model } 2 \\
\text { Multivariable Model of Low Ct including Household Exposure and Symptomatic at Test }\end{array}$} & Household Exposure (20) & 1.3 & $1.03-1.6$ \\
\hline & Symptomatic at Time of Test (34) & 1.4 & $1.15-1.7$ \\
\hline
\end{tabular}

No. Number; $\mathrm{Cl}$ Confidence Interval

presents the results of two logistic regression models. A bivariate model presents household exposure as the sole risk factor for a lower $\mathrm{Ct}$ value of a positive SARS-COV2 PCR test. In that model the association is not statistically significant. The second, multivariable analysis presents a model including both household exposure and being symptomatic at the time of testing, even though these two potential risk factors were not statistically associated with each other as previously presented. In the multivariable model, the association is marginally statistically significant.

\section{Discussion}

Household exposure was associated with lower $\mathrm{Ct}$, and therefore a higher viral load. This supports the hypothesis that contracting illness through household exposure represents a greater viral inoculum than other HCWs with acute SARS-COV-2 infection but without this exposure scenario. This could be related to multiple potential factors (prolonged frequency and duration of exposure, no mask wearing at home, lack of physical distancing, inadequate ventilation). Of course, we cannot exclude the possibility that some of the HCWs with household exposure might also have had a simultaneous, independent additional exposure to SARS-COV-2 either at the workplace or the community.

The association of household source to lower Ct was clarified taking into account being symptomatic, reflecting better model performance when considering both factors together when each was associated with increased odds of the same outcome. Being symptomatic has been shown to be related to lower Ct [7]. Limiting analysis to HCWs with COVID-19 has the advantage of studying a cohort with consistent access to testing and with thorough, standardized contact tracing to ascertain that the household was the likely source of exposure. Nonetheless, this does limit generalizability. A study of HCWs in Switzerland, although it did not analyze Ct data, reported higher risk of seropositivity associated with household but not healthcare-associated SARSCOV-2 contact [8]. Beyond HCWs, studies of professional sports cohorts have reported Ct data, but have not analyzed the relationship between estimated viral load and likely exposure source [ 9, 10]. We also acknowledge the limitation that HCWs with COVID-19 but without a household source of infection served as the referent in our analysis. There was no other appropriate comparison group from within our clinical laboratory as the patient population served was quite older and had underlying comorbidities. Another limitation of this study is its relatively small sample size, although this does not account for the statistical associations we observed. Nonetheless, any non-systematic misclassification of risk factors that would weaken associations (widening confidence intervals) would be magnified in a relatively small study cohort. The association of household exposure with lower SARS-COV-2 Ct that we observed suggests that greater viral inoculum could lead to a higher viral load in infection and may provide insight into this disease among HCWs. This could, if confirmed in other studies, inform case surveillance, contact tracing, and other aspects of occupational case management, with the caveat that given its variability, Ct should not guide clinical management.

\section{Abbreviations \\ HCW: Health care work; Ct: Cycle threshold; OR: Odds ratio; Cl: Confidence Interval}

\section{Acknowledgements}

Not applicable.

\section{Authors' contributions}

AC and PDB carried out the data extraction and data analysis. SD, PDB, and $\mathrm{HL}$ originally conceived of the analysis. All authors collaborated in drafting and reviewing the manuscript. The author(s) read and approved the final manuscript.

\section{Funding}

Dr. Chien was supported in part by the U.S. Health Research Services Administration (HRSA) training award D33HP31668.

\section{Availability of data and materials}

Data sharing is not applicable to this article as no datasets were generated or analyzed during the current study.

\section{Declarations}

Ethics approval and consent to participate

This report is an outgrowth of quality improvement efforts and was designated as exempt from further institutional review for research involving human subjects.

Consent for publication

No personal identifying data were included.

Competing interests

The authors declare that they have no competing interests. 


\section{Author details}

'Occupational and Employee Health Section and Infectious Disease Section, Medical Service and Laboratory Medicine Service, San Francisco Veterans Affairs Health Care System, 4150 Clement St., San Francisco, CA 94121, USA. ${ }^{2}$ Division of Occupational and Environmental Medicine, Department of Medicine, University of California San Francisco, San Francisco, USA.

${ }^{3}$ Occupational and Environmental Health Nursing, Community Health Systems, School of Nursing, University of California San Francisco California, San Francisco, USA. ${ }^{4}$ Department of Laboratory Medicine, University of California San Francisco, San Francisco, USA. ${ }^{5}$ Division of Infectious Disease, Department of Medicine, University of California San Francisco, San Francisco, USA.

Received: 28 April 2021 Accepted: 27 July 2021

Published online: 04 August 2021

\section{References}

1. Rao SN, Manissero D, Steele VR, Pareja J. A systematic review of the clinical utility of cycle threshold values in the context of COVID-19. Infect Dis Ther. 2020;9(3):573-86. https://doi.org/10.1007/s40121-020-00324-3.

2. Infectious Diseases Society of America and Association for Molecular Pathology. IDA and AMP joint statement on the use of SARS-CoV-2 PCR cycle threshold (Ct) values for clinical decision-making. March 12, 2021. https://www.idsociety.org/globalassets/idsa/public-health/covid-19/idsa-a mp-statement.pdf (accessed 6 July 2021).

3. Domeracki S, Clapp RN, Taylor K, Lu CM, Lampiris H, Blanc PD. Cycle threshold to test positivity in COVID-19 for return to work clearance in health care workers. J Occup Environ Med. 2020;62(11):889-91. https://doi. org/10.1097/JOM.0000000000001996.

4. Dillner J, Elfström KM, Blomqvist J, Engstrand L, Uhlén M, Eklund C, et. al. High amounts of SARS-CoV-2 precede sickness among asymptomatic health care workers. J Infect Dis 2021;224:14-20. doi: https://doi.org/10.1093/infdis/ jiab099, 1.

5. Madewell ZJ, Yang Y, Longini IM Jr, Halloran ME, Dean NE. Household transmission of SARS-CoV-2: a systematic review and meta-analysis. JAMA Netw Open. 2020;3(12):e2031756. https://doi.org/10.1001/jama networkopen.2020.31756.

6. Luo L, Liu D, Liao X, Wu X, Jing Q, Zheng J, et. al. Contact settings and risk for transmission in 3410 close contacts of patients with COVID-19 in Guangzhou, China : a prospective cohort study. Ann Intern Med 2020; 173(11):879-887. doi: https://doi.org/10.7326/M20-2671.

7. Arons MM, Hatfield KM, Reddy SC, Kimball A, James A, Jacobs JR, et al. Presymptomatic SARS-CoV-2 infections and transmission in a skilled nursing facility. N Engl J Med. 2020;382(22):2081-90. https://doi.org/10.1056/ NEJMoa2008457

8. Meylan S, Dafni U, Lamoth F, Tsourti Z, Lobritz MA, et. al. SARS-CoV-2 seroprevalence in healthcare workers of a Swiss tertiary care Centre at the end of the first wave: a cross-sectional study. BMJ Open 2021;11(7):e049232. doi: https://doi.org/10.1136/bmjopen-2021-049232.

9. Mack CD, DiFiori J, Tai CG, Shiue KY, Grad YH, Anderson DJ, et. al. SARS-CoV2 transmission risk among National Basketball Association players, staff, and vendors exposed to individuals with positive test results after COVID-19 recovery during the 2020 regular and postseason. JAMA Intern Med 2021; 181(7):960-966. doi: https://doi.org/10.1001/jamainternmed.2021.2114.

10. Mack CD, Osterholm M, Wasserman EB, Petruski-Ivleva N, Anderson DJ Myers E, et. al. Optimizing SARS-CoV-2 surveillance in the United States: insights from the National Football League occupational health program. Ann Intern Med 2021. doi: https://doi.org/10.7326/M21-0319. Epub ahead of print.

\section{Publisher's Note}

Springer Nature remains neutral with regard to jurisdictional claims in published maps and institutional affiliations.

Ready to submit your research? Choose BMC and benefit from:

- fast, convenient online submission

- thorough peer review by experienced researchers in your field

- rapid publication on acceptance

- support for research data, including large and complex data types

- gold Open Access which fosters wider collaboration and increased citations

- maximum visibility for your research: over $100 \mathrm{M}$ website views per year

At BMC, research is always in progress.

Learn more biomedcentral.com/submissions 